Olga Stangej ${ }^{1 *}$, Inga Minelgaite ${ }^{2}$, Christopher Leupold ${ }^{3}$ 1 Vilnius University Business School, Lithuania 2 School of Business, University of Iceland, Iceland

${ }^{3}$ Elon University, Elon, U.S.A

\title{
Contouring Sustainability: Cultural Configurations of Nordic Firms
}

DOI: 10.7595/management.fon.2020.0015

Abstract:

Research Question: This article outlines and explains a unique cultural configuration of organizations in the Nordics - the region that embodies linkages between sustainability, societal, cultural context, and organizational culture. Motivation: Our goal was to offer a holistic approach that incorporates national and organizational perspectives as they apply to Nordic organizations' culture, as culture is typically examined either through a) the lens of its national culture, or, b) through specific assumptions, beliefs and values, and artifacts that exist in the institution itself. Idea: Building on theoretical underpinnings from models of national culture and a separate framework for examining organizational culture, we examine how the links among cultural artifacts, espoused values and beliefs, and basic underlying assumptions are established in Nordic organizations and how they complement previous findings about the Nordic cultural cluster in general. Findings: This integrative analysis suggests that the highly prominent central tendencies of the Nordics across core cultural dimensions are deeply rooted as basic underlying assumptions within the Nordic culture that are ultimately translated into a set of observable artifacts. Likewise, the moderately expressed tendencies have not yet been transformed into underlying assumptions and are accompanied with mixed artifacts. Contribution: This paper expands our existing understanding regarding the interplay of national and organizational culture in specific cultural cluster - Nordic cluster, which is characterized by high achievements in sustainability-orientated societal-level outcomes.

Keywords: Nordic culture, cultural configurations, organizational culture

JEL Classification: M10

\section{Introduction}

Organizational development towards sustainability is a domain of holistic inquiry, where internal, external, and connecting drivers must be considered (Lozano \& von Haartman, 2018). Organizational culture, that has been repeatedly documented to be the cornerstone of corporate sustainability (Linnenluecke \& Griffiths, 2010), can be considered a holistic manifestation of these drivers. Therefore, context-specification investigation of organizational culture pertains to building our knowledge on development of organizational sustainability. As Parodi (2015) notes, sustainability is a highly cultural phenomenon and "increased incorporation of cultural-scientific and cultural-theoretical considerations" (p.169) will contribute to the advancement of the discourse on sustainable development. Such considerations of the linkage between organizational culture and sustainable development are also inextricably linked with the societal culture, since, as Lozano and von Haartman (2018) have noted, "no organization is an island" and organizational contexts, together with goals, will play a role in "their quest to better contribute to sustainability" (p. 520).

The Nordic region embodies these linkages between sustainability, societal cultural context, and organizational culture. The region has of late enjoyed a place in the global spotlight for the enviable success it has had in achieving a variety of sustainability-orientated societal-level outcomes (Minelgaite, Guðmundsdóttir, Guðmundsdóttir, \& Stangej, 2018). For example, the Nordics are recognized as the global leaders in gender equality and for their ambitious climate and energy policies (Word Economic Forum, 2017). Furthermore, Nordic countries are performing particularly well on indicators related to employment and education (State of the Nordic Region, 2016). Among a variety of other factors, the Nordic values of 
modesty, trust and care are typically highlighted as culturally broad and pervasive factors that underly these and other impressive societal-level achievements of the Nordics.

At the same time, the Nordic region is also increasingly attracting the attention of organizational science scholars due to its equally impressive achievements in management (Minelgaite, et al., 2018). For example, Nordic employees are noted as some of the world's most motivated workers (Eriksen, Kruse, \& Larsen, 2006) and Nordic companies are recognized worldwide for their innovativeness, competitiveness, and productiveness (Chen, 2014). At the level of organizations, the same values of modesty, trust and care underlie the stability orientation in management and the high focus on stakeholder management (Kvande \& Brøve, 2012) typical of Nordic companies. Research suggests that such organizational success is achieved through a special synergy between cultural norms and institutional structures that encourage quality relationships between companies and their stakeholders (Gjølberg, 2010). These organizational outcomes are notable given that the Nordic cultural context, particularly with its underlying values and resultant leadership style, is incompatible with typical Anglo-American leadership narrative (Sund, 2016) that has come to be the de facto prescribed approach in management literature.

Taken together, the broad national culture of the Nordics and the more specific cultures of the organizations within it present an interesting point of study. This includes the work environment, where leaders routinely apply the norms of honesty and consensus and create an effective set of leadership principles that competitively position Nordic companies in the global market (Chen, 2014); that is part of a regional culture where economic interests are nested within broader societal ones (Midttun, Gautesen, \& Gjølberg, 2006). This specific type of success, which may at points diverge from other cultures' typical definitions and criteria, stems from and perpetuates a certain Nordic code that management scholars have tried to decipher either by focusing on Nordic societal culture alone or on particular success stories of Nordic organizations. As will be elaborated here, a sole reliance on either of these approaches may not be sufficient for thoroughly analyzing or completely understanding the organizational culture nested within its cultural (or national) cluster. However, the conceptualization offered here responds to the calls from prominent scholars to integrate and adapt both levels of culture - broad national and more specific organizational - in order to build a better understanding for business and management in cross-cultural settings (Nardon \& Steers, 2009).

Research provides strong evidence that culture, both national and organizational, substantially affects organizational outcomes (Oyserman, Kemmelmeir, \& Coon, 2002), and hence, cannot be ignored. The effects of culture on organizational processes and outcomes are quite far-reaching including leadership (e.g., Chan \& Drasgow, 2001), decision-making (e.g., Mitchell, Smith, Seawright, et al., 2000); emotions and work-related attitudes (e.g., Harpaz, Honig, \& Coetsier, 2002), and allocation of rewards (e.g., Gomez, Kirkman, \& Shapiro, 2000). One might argue that globalization and tighter interconnectedness among nations diminishes the relevance of focusing on specific national cultures. However, an increasing body of research suggests that new challenges that globalization brings have amplified companies' needs to more precisely understand specific local cultures in order to engage in better cross-cultural management (Bhagat \& Steers, 2009; Mihic, Shevchenko, Gligorijevic, \& Petrovic, 2019). Indeed, the national culture profoundly influences organizational culture, and thus must be better understood (Selnes, 1996) in today's everchanging business environment. However, in order to contribute to a more effective cross-cultural management for business and advancement of theory, scholars need to focus on the role of culture and cultural variations in macro- and micro-level processes in both specific organizational contexts, as well as national ones (Bhagat \& Steers, 2009).

Therefore, the objective here is to provide an integrated portrait of both cultural perspectives, national and organizational, within the Nordic cluster, and in this way articulate a more complete cultural configuration of Nordic organizations. Building on and synthesizing the theoretical underpinnings of some of the most prominent models of national culture, we suggest a framework to augment our understanding via the incorporation of an organizational perspective. Our theoretical insights are contextualized within the specific Nordic cultural cluster and provide an integrated view of not only its core cultural dimensions, but also of the basic underlying assumptions, espoused beliefs and values, and artifacts and observed perceptions found in Nordic organizations.

\section{Mapping the Organizational Culture: A Theoretical Framework}

The landscape of cross-cultural studies is dominated by a number of impactful models that have established a solid framework for empirical research. However, the differences in the individual models' orientations and foci on various different cultural aspects result in a rather fragmented set of empirical studies. Nardon and 
Steers (2009) argued that the advancement of cross-cultural organizational research should build on commonalities and strive to achieve convergence among the existing models of national culture instead of debate on individual validities or development of new ones. As such, Nordon and Steers (2009) sought to synthesize the six leading models of the national culture authored by Kluckhohn and Strodtbeck, Hofstede, Hall, Trompenaars, Schwartz, and House and GLOBE associates. Their synthesis identified the common principal themes that best encapsulated cultural similarities and delineated differences. Nardon and Steers (2009) labelled these dimensional themes, or core cultural dimensions (CCDs), as follows:

- Hierarchy-Equality, which refers to the power distribution in organizations and society;

- Individualism-Collectivism, which refers to the role of individuals and groups in social relationships;

- Mastery-Harmony, which refers to the relationship with the natural and social environment;

- Monochronism-Polychronism, which refers to the organization and utilization of time; and,

- Universalism-Particularism, which refers to the relative importance of rules versus relationships in behavioural control.

Often using models that pre-date Nardon and Steers' (2009), the cross-cultural studies on organizations tackle the deeper levels of culture through cross-cultural dimensions that portray the underlying values and beliefs of given clusters or geographic regions. However, the understanding of organizational culture calls for a more systematic and comprehensive approach. As Leung and Ang (2009) point out, the abundance of management studies through a lens of subjective culture, or the one that rests with values, beliefs, and assumptions; eventually narrows the focus and diminishes the conceptualization of institutions as entities that are themselves distinctively cultural in nature.

The seminal works by Schein, started in the early 1980s, set the framework for an analysis of the culture within an organization. These works complement the objective-subjective view on culture, proposed by Triandis (1972) and Stewart and Bennett (1991), which acknowledges the existence of objective components (observable artifacts) and subjective components (psychological aspects) of culture. Schein $(1984 ; 2010)$ suggests that culture manifests itself through three levels: artifacts, espoused beliefs and values, and basic underlying assumptions; each of which progresses from a surface level one to much deeper levels. At the surface level, tangible and overt culture manifestations can be directly observed and experienced. While it may be difficult to deduce the culture solely from artifacts, Schein suggests that the deeper levels serve as suitable perspectives for understanding the culture that they reflect. The two deeper layers, espoused beliefs and values, and underlying assumptions; are the conscious elements and form the basis of the culture. Espoused beliefs, values, norms, and rules of behaviour guide the members of the culture and are practiced and exhibited by them to convey and reinforce the culture both to themselves and outsiders. As Schein (2010) contends, values and beliefs have a potential to become shared, embedded, unconscious basic underlying assumptions. However, for this transformation to take place, the values must occasionally be tested. In the case of values that concern aesthetic or moral matters and cannot be directly tested, social validation is required, i.e., the confirmation of a value that emerges through the shared social experience of a group (Schein, 2010).

As Schein (2010) notes, an underlying assumption evolves from a value or hypothetical belief to a fundamental assumption that "nature really works this way" (p. 27). Schein further distinguishes assumptions from dominant value orientations, as the latter considers what solutions to problems individuals prefer amongst a number of alternatives. Instead, underlying assumptions leave no room for other alternatives they become taken for granted realities. Hence, direct exploration and examination of organizational culture through the national lens also can lead to a partial disregard of the interaction between the institutional context and the national culture. Such an approach also omits, what one might label, the flow of culture, or the sequence from artifacts to espoused beliefs and values to basic underlying assumptions. While it points at the dominant orientation of the culture, sole reliance on the national culture or isolation of one layer from the other may limit the comprehensiveness of the organizational culture. Finally, it can potentially diminish the interrelationships between layers that may result in broken links between, for example, the artifacts or observer perceptions, and the espoused beliefs and values. For example, one of the most common peculiarities of the Nordic culture is the emotionally non-laden or distant communication that a western observer might erroneously perceive as indifferent or even subtle hostility. Similarly, the relaxed atmosphere in Icelandic workplaces can often be mistaken for a somewhat nonchalant workplace attitude with little emphasis on results. The establishment of the links among the three layers of culture may be essential in structuring the cultural configurations and understanding how underlying assumptions, beliefs, and values translate into artifacts and manifest in practice.

Therefore, to unravel the cultural configuration of Nordic organizations, we embrace all three layers through which the culture manifests: artifacts and observer perceptions, espoused beliefs and values, and basic underlying assumptions. We further embed the core cultural (national) dimensions of the Nordic cluster that 
are interrelated with the organizational culture into the framework. The artifacts represent the observable, outer layer of the organizational culture. The espoused beliefs and values are then nested as a deeper level of conscious elements of the culture. Finally, the deepest layers involve both core cultural dimensions and the basic underlying assumptions. It is proposed here that the central tendencies across a cluster's core cultural dimensions, or dominant value orientations, permeate the organizational culture and its underlying assumptions. It is assumed that the basic underlying assumptions actually drive the organizational culture. In line with Schein (2010) it is assumed that these assumptions guide the perceptions and behaviour of individuals, regardless of possible alternatives that dominant value orientation otherwise takes into account. This approach is captured in Figure 1.

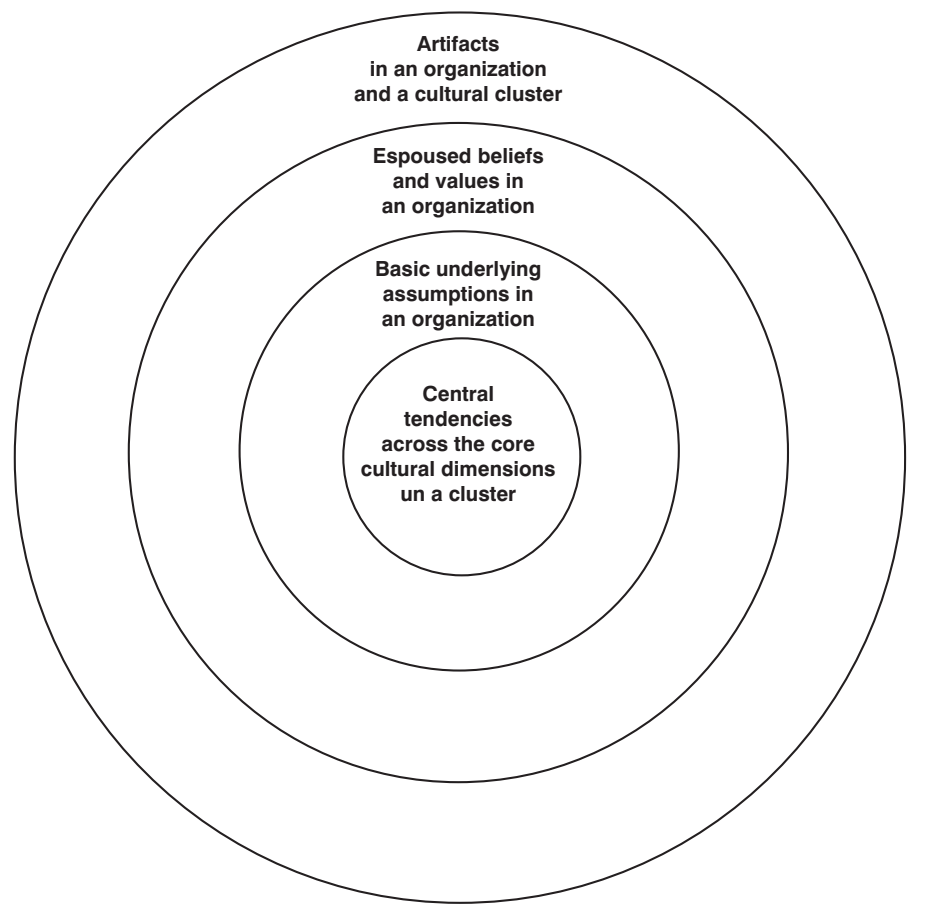

Figure 1: Conceptual framework for analyzing the cultural configurations of organizations. Source: Authors, based on Nardon and Steers (2009) and Schein (2010)

In line with the suggestion by Leung and Ang (2009), we simultaneously rely on both cultural and institutional perspectives and consider organizational culture together with its subjective and objective parts. In this vein, cultural perspective involves ecology (climate, terrain, environmental resources, disaster proneness), objective culture (human-made physical environment, other overt, objective elements, formal rules), and subjective culture (norms, values, beliefs, and knowledge). The institutional perspective encompasses regulatory, normative, and cognitive dimensions. This proposed model further builds on the integrative summary of core cultural dimensions by Nardon and Steers (2009) and Schein's (2010) framework as an approach to unravelling the organizational culture and its configuration in the Nordic countries.

We adopt the definition of cultural configuration suggested by Leung and Ang (2009) in extension to traditional definitions steeped in the cognitive approach, such as the ones by, for example, Hofstede (1980). Leung and Ang (2009) thus conceptualize culture as, "the configuration of basic assumptions about humans and their relationship to each other and to the world around them, shared by an identifiable group of people," which is "manifested in individuals' values and beliefs, in expected norms for social behaviour, and in artifacts such as social institutions and physical items".

Table 1 reflects the core cultural dimensions and central tendency-based assessments (i.e., the general 'means', so to speak) across countries in the Nordic cluster. The left-most column lists the dimensions derived by Nardon and Steers (2009), and the one immediately adjacent to it provides the respective Nordic central tendency for each. The following column headings are cultural layers in line with Schein's (1984; 2010) framework. The result is a matrix of core national cultural dimensions by layers of organizational cultural dimensions, with each cell summarizing the particular intersection of the two cultures - the cluster and the organizational. 
Table 1: Core cultural dimensions and layers for the Nordic cluster

\begin{tabular}{|c|c|c|c|c|}
\hline $\begin{array}{l}\text { Core Cultural } \\
\text { Dimension }\end{array}$ & $\begin{array}{c}\text { Central } \\
\text { Tendency of } \\
\text { the Nordics }\end{array}$ & $\begin{array}{l}\text { Basic Underlying } \\
\text { Assumptions }\end{array}$ & $\begin{array}{c}\text { Espoused } \\
\text { Beliefs \& Values }\end{array}$ & $\begin{array}{c}\text { Artifacts \& Observer } \\
\text { Pereptions }\end{array}$ \\
\hline $\begin{array}{l}\text { (National } \\
\text { Culture) }\end{array}$ & $\begin{array}{l}\text { (Nordic } \\
\text { Culture) }\end{array}$ & $\begin{array}{l}\text { (Organization } \\
\text { Culture) }\end{array}$ & $\begin{array}{l}\text { (Organization } \\
\text { Culture) }\end{array}$ & $\begin{array}{l}\text { (Organization } \\
\text { Culture) }\end{array}$ \\
\hline $\begin{array}{l}\text { Hierarchy- } \\
\text { Equality }\end{array}$ & $\begin{array}{l}\text { Strongly } \\
\text { egalitarian }\end{array}$ & $\begin{array}{l}\text { Every individual } \\
\text { must be treated } \\
\text { equally }\end{array}$ & Equality & $\begin{array}{l}\text { Direct and informal } \\
\text { communication (first } \\
\text { names, ...), legal } \\
\text { gender equality } \\
\text { regulation }\end{array}$ \\
\hline $\begin{array}{l}\text { Individualism- } \\
\text { Collectivism }\end{array}$ & $\begin{array}{l}\text { Moderately } \\
\text { collectivistic }\end{array}$ & Non-stabilized & $\begin{array}{l}\text { Collective welfare, } \\
\text { individual welfare }\end{array}$ & \\
\hline $\begin{array}{l}\text { Mastery- } \\
\text { Harmony }\end{array}$ & $\begin{array}{l}\text { Moderately } \\
\text { harmonic }\end{array}$ & Non-stabilized & & \\
\hline $\begin{array}{l}\text { Monochronism } \\
\text { - Polychronism }\end{array}$ & $\begin{array}{l}\text { Moderately } \\
\text { monochronic }\end{array}$ & Non-stabilized & & \\
\hline $\begin{array}{l}\text { Universalism- } \\
\text { Particularism }\end{array}$ & $\begin{array}{l}\text { Strongly } \\
\text { universalistic }\end{array}$ & & & \\
\hline
\end{tabular}

Source: Authors

\section{Hierarchy-Equality}

In a situation when equality as a shared value is deeply rooted in a culture to the point that it becomes an underlying assumption, it results into an egalitarian culture. From such a culture in the hierarchy-equality dimension emerges a balanced distribution of power and authority across society and its members, where broad and equal participation and fairness are promoted (Dragicevic \& Mihic, 2020; Nardon \& Steers, 2009; Schwartz, 1994). In the Nordic cluster, an underlying assumption that every individual must be treated equally permeates all societal and organizational domains. Eventually, this underlying assumption attains the level of artifacts; perhaps the one of the most prominent among the Nordics is a legal regulation around balanced gender representation on boards. Less formal but equally representative of the assumption of equality include people addressing each other on a first name basis among all members. Also evident is a more equal distribution of rewards and resources, and a general acknowledgement that everyone is seen as an equal participant.

The strong sense of egalitarianism in Nordic organizations is readily apparent to an outside observer, particularly one who is more familiar with traditional organizational power structures. In contrast to the classical vertical structure with authority centralized with a few at the top, Nordic organizational structures are more horizontal with power dispersed more widely. Likewise, from an organizational communication perspective, information is transmitted, even from top management to employees, more openly and directly, rather than through filtered channels or levels as would be typical in hierarchies. Likewise, compensation policies focus on equitability and lack wide disparities in pay and rewards typical of hierarchical organizations. All these artifacts and many more point at the underlying value of equality and a shared belief that the societal and organizational structures should be built with respect to fundamental equality among its members.

\section{Individualism-Collectivism}

Moderate collectivism in the Nordic cluster emphasizes a certain degree of centrality of groups, including group goals and collective action (Nardon \& Steers, 2009; Trompenaars, 1993), although not to the extent that one would observe in an Asian cluster. However, in early studies by Hofstede (1980), Nordic countries were found to score moderately high on individualism. Although sometimes differing on which of dimensional anchors was chosen as the descriptive label, these authors ultimately include the modifier 'moderate,' suggesting that elements of both are evident in the Nordic culture and that neither far outweighs the others.

This 'moderate' standing is further supported by empirical findings that reflect a combination of individualism and collectivism. One example of these was an early study by Hampden-Turner and Trompenaars (1993) on Swedish management which the authors later characterized as 'social individualism.' The artifacts of social individualism can be primarily captured in the artifact of the social welfare systems, given the widespread reference to the Nordic countries as welfare states. As Hjorth (2008) denotes, individual independence, which has quite important significance in the Nordic culture, has triggered the development of the physical and economic infrastructure which supports it. Here, however, Hjorth (2008) differentiates between the 
Nordic individualism that is supported by the state, and the 'self-made independence' which is perhaps most markedly inherent in the culture of United States. In Denmark, the move from collectivism to individualism has been evident in changes in the areas of the welfare state (Kvist \& Greve, 2011). In contrast, Vaara, Tienari, and Irrmann (2007) contend that Danish individualism may be juxtaposed with the Swedish "communitarian, consensus-seeking society" (p. 226). All these variations are evident in the light of, for example, essentially the same shift from welfare to workfare in social insurance systems that took place in both Denmark and Sweden from the early 1990s to 2000s (Kananen, 2012).

When one moves towards the entrepreneurial domain, as Hjorth (2008) suggests, the public perception of individual independence in the Nordics is shifted from a concept of a 'natural right' to an idea of a 'possibility.' Likewise, institutional structures and management practices in the Nordic cluster embody relationships between stakeholders and the companies (Gjølberg, 2010). This is just one more example of the cluster's unique positioning on the values of individualism and collectivism, which in turn emerge into artifacts in organizational practices.

\section{Mastery-Harmony}

Based on Schwartz' (1994) framework, the mastery-harmony cultural dimension that Nardon and Steers (2009) more thoroughly identified, refers to the extent of achievement-orientation and control-seeking behaviour over the natural and social worlds. From a relationship perspective, moderate orientation towards harmony within the Nordic cluster reflects the value of interpersonal relationships over achievement, living in harmony with nature and adjusting to the natural and social environments, and a general emphasis on social progress and the welfare of others. The Nordics' standing on this dimension also refers to striving to achieve a healthy quality of life more than achievements, nurturing traditions and expressing a certain scepticism towards change, and preferring seniority-based intrinsic rewards. Finally, there is a general emphasis on economy, harmony, and modesty; and practicing an overall rather passive, reactive, and 'feminine' approach (Nardon \& Steers, 2009).

Yet, as in the case of moderate tendency towards both individualism and collectivism, the positioning of organizational culture in the Nordic cluster is not uniform with regard to the mastery-harmony dimension. In this domain, Nordic organizations are well-known for their emphasis on harmony and for their ability to match their economic goals with the collective interests of society (Midttun et al., 2006). However, as an example of Iceland illustrates, this value, although it may be shared, is not necessarily transformed into a basic underlying assumption. For instance, the role of social responsibility in corporate culture only began to grow notably after the financial crisis of 2008 shook the society and the business landscape and triggered the reconsideration of values, beliefs, and instigated change in the organizational culture (Jónsdóttir \& Steinpórsson, 2010).

\section{Monochronism-Polychronism}

The moderately monochronic tendency in the Nordic cluster refers to a preference for sequential attention to individual tasks and a reliance on methodical approaches to planning and implementation; in other words, the Nordics adopt a linear, single-minded and job-centered approach to their work (Nardon \& Steers, 2009). Punctuality and precise time management are the norm, as are one's commitment to their job and their organization, separation of work and personal life, and a focused and dedicated approach to work (Nardon \& Steers, 2009).

The Nordic cluster's tendency towards moderation on the CCDs applies again to the balance between monochronism and polychronism in the Nordic organizations. The process of switching from the one end of the continuum towards the other can be illustrated through a well-known example of the corporate meetings. In the Nordic working environment, which is often characterized as somewhat relaxed, being late is acceptable; however, only to a certain degree. Commitment to one's job and colleagues and the expectations to dutifully attend and actively contribute to meetings are general professional expectations for everyone. However, if a situation presents itself where an employee's need to attend to child or family issues competes or conflicts with professional duties; commitment to the family and other important personal life duties may override the professional responsibilities.

While this sensitivity to employees' private lives and the promotion of healthy work-life balance by the Nordic organizations is often celebrated, a question of differentiation between acceptable and unacceptable behaviour remains open. As such, this flexibility in practice also indicates that individuals themselves make their own choices regarding their work lives and personal lives; and in reality, there is a variance in the degree to which pole people gravitate. In line with Schein's framework (2010), it further suggests that there is no universal solution and reliance on one or another belief that is taken for granted. Hence, beliefs and 
values associated with the monochronism and polychronism are not yet transformed into basic underlying assumptions.

\section{Universalism-Particularism}

The strongly universalistic culture in the Nordic cluster is evident in a strong reliance on the rules and norms and intolerance for violating them. As such, individuals' behaviours are uniformly regulated by a variety of mechanisms including rules, laws, formal policies, standard operating procedures, and social norms. Moreover, these prescribed behaviours and the expectation that they are adhered to are not only accepted but strongly supported by societal members. These universalistic practices not only promote a hogher efficiency and predictability in society, but also preserve a sense of fairness and messaging that everyone is expected to follow the same rules regardless of their status. As strong universalists, the Nordics focus more on commonalities among the members to preserve a sense of fundamental equality rather than accentuate individual differences that call out some as more exceptional than others.

Once transferred to organizational culture and coupled with egalitarianism and moderate uncertainty avoidance, this central tendency manifests through sets of corporate policies. These may include both clear regulations and rules in human resource management practices (Warner-Søderholm \& Cooper, 2016). Still, whilst organizational culture, just like societal culture, is based on the expectation of following the rules, these may often remain unspoken or inexplicit. Such a tendency may be linked with the balance between formality and flexibility (Andreasson \& Lundqvist, 2018), which enables organization members to simultaneously nurture non-restrictive rules and autonomy. Here, however, questions that are still rather open, tackle when and how rules are to be explicitly communicated. Warner-Søderholm and Cooper (2016) noted, the relationship between cultural research and business communication practices, although being evident, remains under-investigated in the Nordics. Thus, a more nuanced understanding of enacting universalism through communication practices, and especially in relation to sustainability, is yet to be achieved.

\section{Conslusion}

Through analysis of cultural configurations in the Nordic organizations, this paper presents a twofold contribution. First, it maps the organizational culture in the Nordics by describing the attributed configurations across core cultural dimensions. Second, by combining the national and organizational perspectives on culture, it suggests that the single perspective in isolation may provide a limited view that disregards the underlying links between the artifacts, espoused values and beliefs, and the basic underlying assumptions. A deeper investigation into the example of organizations within the Nordic cluster suggests that the highly expressed dominant value orientations are often transformed into basic underlying assumptions, traced in the cultural artifacts. On the contrary, moderate ratings across the core cultural dimensions suggest that the values or beliefs are either not fully shared by the groups or have not yet been socially validated and completely transformed into basic underlying assumptions. While these insights emerge building on examples from organizations in the Nordic cluster, further analyses in different clusters can be anticipated in order to support or contradict them.

\section{REFERENCES}

[1] Andreasson, U., \& Lundqvist, M. (2018). Nordic leadership. Nordic Council of Ministers.

[2] Bhagat, R.S., \& Steers, R.M. (2009). Cambridge handbook of culture, organizations, and work. Cambridge, UK: Cambridge University Press.

[3] Chan, K.Y., \& Drasgow, F. (2001). Toward a theory of individual differences and leadership: understanding the motivation to lead. Journal of Applied Psychology, 86(3), 481-498. DOI: 10.1037/00219010.86.3.481

[4] Chen, M.H. (2014). Elements of the Nordic leadership framework, origins, and transferability. Accessed at https://surface.syr.edu/cgi/viewcontent.cgi?article $=1776 \&$ context=honors_capstone

[5] Dragicevic I., \& Mihic M. (2020). Women leadership in public sector - Evidence from Serbia. Lex localis - Journal of Local Self-Government, 18(2). DOI: 10.4335/18.2.253-270(2020)

[6] Eriksen, T.T., Kruse, M., \& Larsen, G. (2006). The Scandinavian way. Futureorientation 5. Copenhagen Institute for Future Studies.

[7] Gjølberg, M. (2010) Varieties of corporate social responsibility (CSR): CSR meets the Nordic model. Regulation and Governance, 4, 203-229. DOI: 10.1111/j.1748-5991.2010.01080.x

[8] Gomez, C., Kirkman, B.L., \& Shapiro, D.L. (2000). The impact of collectivism and in-group/out-group membership on the evaluation generosity of team members. Academy of Management Journal, 43(6), 1097-1106. DOI: $10.2307 / 1556338$

[9] Hampden-Turner C., \& Trompenaars, A. (1993). The seven cultures of capitalism: Value systems for creating wealth in the United States, Japan, Germany, France, Britain, Sweden, and the Netherlands. London, UK: Doubleday. 
[10] Harpaz, I., Honig, B., \& Coetsier, P. (2002). A cross-cultural longitudinal analysis of the meaning of work and the socialization process of career starters. Journal of World Business, 37(4), 230-244.

[11] Hjorth, D. (2008). Nordic entrepreneurship research. Entrepreneurship Theory and Practice, 32(2), 313-338. DOI: 10.1111/j.1540-6520.2007.00228.x

[12] Hofstede, G. (1980). Motivation, leadership, and organization: Do American theories apply abroad? Organizational Dynamics, 9(1), 42-63. DOI: 10.1016/0090-2616(80)90013-3

[13] House, R.J. (2004). Introduction. In R. House, P. Hanges, M. Javidan, P. Dorfman, \& V. Gupta (Eds.), Culture, leadership, and organizations: The GLOBE Study of 62 societies. Thousand Oaks, CA: Sage.

[14] Jónsdóttir, H.D., Steinpórsson, R.S. (2010). Samfélagsleg ábyrgð fyrirtækja og sjálfbærni. In E. Hilmarsson, S. Ólafsson, \& T. Christiansen (Eds.) Vorráðstefna Viðskiptafræðistofnunar Háskóla Íslands (pp. 58-68).

[15] Kananen J. (2012). Nordic paths from welfare to workfare: Danish, Swedish and Finnish labour market reforms in comparison. Local Economy, 27(5-6), 558-76. DOI: 10.1177/0269094212445351

[16] Kluckhohn, F.R., \& Strodtbeck, F.L. (1961). Variations in value orientations. Evanston, IL: Row, Peterson.

[17] Kvande, E., \& Brøve, H.E., (2012). The Nordic model in a global company situated in Norway: Challenging institutional orders? Nordic Journal of Life Studies, 2(4), 117-134. DOI: $10.19154 /$ njwls.v2i4.2307

[18] Kvist, J., \& Greve, B. (2011). Has the Nordic welfare model been transformed? Social Policy \& Administration, 45(2), 146-60. DOI: 10.1111/j.1467-9515.2010.00761.x

[19] Leung, K., \& Ang, S. (2009). Culture, organizations, and institutions: An integrative review. In R. S. Bhagat \& R. M. Steers (Eds.) Cambridge handbook of culture, organizations, and work. New York: Cambridge University Press.

[20] Linnenluecke, M. K., \& Griffiths, A. (2010). Corporate sustainability and organizational culture. Journal of world business, 45(4), 357-366. DOI: 10.1016/j.jwb.2009.08.006

[21] Lozano, R., \& von Haartman, R. (2018). Reinforcing the holistic perspective of sustainability: analysis of the importance of sustainability drivers in organizations. Corporate Social Responsibility and Environmental Management, 25(4), 508-522. DOI: 10.1002/csr.1475

[22] Midttun, A., Gautesen, K. \& Gjølberg, M., (2006). The political economy of CSR in western Europe. Corporate Governance, 6(4), 369-385.

[23] Mihic, M., Shevchenko, S., Gligorijevic, E., \& Petrovic D. (2019). Towards strategic corporate social responsibility approach in international projects-Review of south-south cooperation: A case study of Chinese projects in Angola, Sustainability, 11(10), 1-16. DOI: 10.3390/su11102784

[24] Minelgaite, I., Guðmundsdóttir, S., Guðmundsdóttir, Á. E., \& Stangej, O. (2018). Demystifying Leadership in Iceland: An Inquiry Into Cultural, Societal, and Entrepreneurial Uniqueness. Springer.

[25] Mitchell, R.K., Smith, B., Seawright, K.W., \& Morse, E.A. (2000). Cross-cultural cognitions and the venture creation decision. Academy of Management Journal, 43(5), 974-993. DOI: 10.2307/1556422

[26] Nardon, L., \& Steers, R.M. (2009). The culture theory jungle: Divergence and convergence in models of national culture. In R.S. Bhagat \& R.M. Steers (Eds.) Cambridge handbook of culture, organizations, and work (pp. 3-22). Cambridge, UK: Cambridge University Press.

[27] Oyserman, D., Kemmelmeier, M., \& Coon, H. M. (2002). Cultural psychology, a new look: Reply to Bond (2002), Fiske (2002), Kitayama (2002), and Miller (2002). Psychological Bulletin, 128(1), 110117. DOI: $10.1037 / 0033-2909.128 .1 .110$

[28] Parodi, O. (2015). The missing aspect of culture in sustainability concepts. In Theories of Sustainable Development; Enders, JC, Remig, M., Eds, 169-187. Routledge: London, UK

[29] Ronen S., \& Shenkar, O. (1985) Clustering countries on attitudinal dimensions: A review. Academy of Management Review, 10, 435-454. DOI: 10.5465/amr.1985.4278955

[30] Schein, E.H. (1984). Culture as an environmental context for careers. Journal of Organizational Behavior, 5(1), 71-81. DOI: 10.1002/job.4030050107

[31] Schein, E.H. (2010). Organizational culture and leadership (4th ed.). San Francisco, CA: JosseyBass.

[32] Schwartz, S. (1994). Are there universal aspects in the content and structure of values. Journal of Social Issues, 50, 19-45. DOI: 10.1111/j.1540-4560.1994.tb01196.x

[33] Selnes, F. (1996). Market orientation in United States and Scandinavian companies: A cross-cultural study. Journal of Scandinavian Management, 12, 139-157 DOI: 10.1016/0956-5221(95)00053-4

[34] State of the Nordic Region (2016). Accessed at http://norden.divaportal.org/smash/get/diva2:906913/FULLTEXT01.pdf

[35] Stewart, E.C., \& Bennett, M.J. (2005). American cultural patterns: A cross-cultural perspective (2nd ed.) London, UK: Nicholas Brealey Publishing.

[36] Sund, B. (2016). Small fish in a big pond: Norwegian leadership. Accessed at https://www.researchgate.net/publication/312222301_Nordic_leadership 
[37] Triandis, H. C. (1972). The analysis of subjective culture. Oxford, UK: Wiley-Interscience.

[38] Vaara E., Tienari J., \& Irrmann, O. (2007). Crafting an international identity. In L. Lerpold, D. Ravasi, J. van Rekom, \& G. Soenen (Eds.) Organizational identity in practice (pp. 215-230). London, UK: Routledge.

[39] Warner-Søderholm, G., \& Cooper, C. J. (2016). Be careful what you wish for: Mapping nordic cultural communication practices values in the management game of communication, International Journal of Business and Management, 11(11), 48-59 DOI: 10.5539/ijbm.v11n11p48

[40] World Economic Forum (2017). The Global Gender Gap Report, accessed at http://www3.weforum.org/docs/WEF_GGGR_2017.pdf

Received: 2020-04-14

Revisions requested: 2020-05-16

Revised: 2020-05-25

Accepted: 2020-05-30

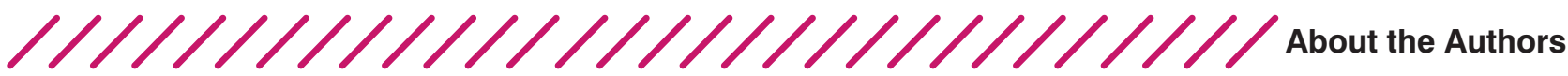

\section{Olga Stangej \\ Vilnius University Business School, Lithuania olga.stangej@gmail.com}

Dr. Olga Stangej is an Associate Professor at Vilnius University Business School (Lithuania), where she delivers courses on entrepreneurship and is in charge of the Entrepreneurship MBA programme. Her research, broader educational activities, and projects lie within the domains of leadership and family businesses.

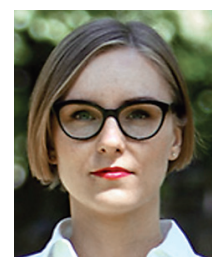

$$
\begin{array}{r}
\text { Inga Minelgaite } \\
\text { School of Business, University of Iceland, Iceland } \\
\text { inm@hi.is }
\end{array}
$$

Dr.Inga Minelgaite is an Associate Professor at the School of Business, University of

Iceland and Head at Institute for Project Management. Her main field of research is cross-cultural leadership and leadership in project management. Inga has published a number of articles, book chapters, and written a book on leadership in Iceland 'Demystifying leadership in Iceland'. Inga is one of the leaders of global FEELS (Fellow endorsed effective leadership and sustainability) research network. Inga has more than

15 years middle and top management experience in various business sectors in multiple countries.

\section{Christopher Leupold Elon University, Elon, U.S.A cleupold@elon.edu}

Christopher R. Leupold, Ph.D., is the Isabella Cannon Professor of Leadership and Professor of Psychology at Elon University, located in North Carolina, U.S.A. He earned his B.A. in psychology from the University of Notre Dame and his M.A. and Ph.D. in industrial/organizational psychology at The University of North Carolina and Wayne

State University, respectively. His primary teaching and research interests are in leadership assessment and development, teams, and organization development. Dr.

Leupold also has over twenty-five years of experience consulting in these areas to organizations around the world, ranging from small start-up to Fortune 50 companies. $\mathrm{He}$ is a frequent publisher in academic journals in his field and an active member of the Society for Industrial/Organizational Psychologists and American Psychological Society. 